\title{
Correction to "High-Throughput Screening of Transient Receptor Potential Channel 1 Ligands in the Light of the Bioluminescence Resonance Energy Transfer Technique"
}

\author{
In the above article [Chappe Y, Michel P, Joushomme A, Barbeau S, Pierredon S, Baron L, \\ Garenne A, De Gannes FP, Hurtier A, Mayer S, Lagroye I, Quignard J-F, Ducret T, Compan \\ V, Franchet C, and Percherancier Y (2021) Mol Pharmacol 100:237-257; DOI: https://doi.org/ \\ 10.1124/molpharm.121.000271], the article title was incorrect due to a compositor error. \\ The correct article title is: "High-Throughput Screening of TRPV1 Ligands in the Light of the \\ Bioluminescence Resonance Energy Transfer Technique." \\ The HTML and PDF versions of the article have been corrected. \\ The compositor apologizes for any inconvenience this may have caused. \\ https://doi.org/10.1124/molpharm.121.000271
}

